- -9625 -(2)

Report No.

INS-0-96-OR
U.S. Department of Inergy

Office of Inspector General

\title{
Report on \\ Selected Concerns Regarding Property Accountability at the Continuous Flectron Beam Accelerator Facility
}

DISTRIBUTION OF THIS DOCUMENT IS UNLIMITED

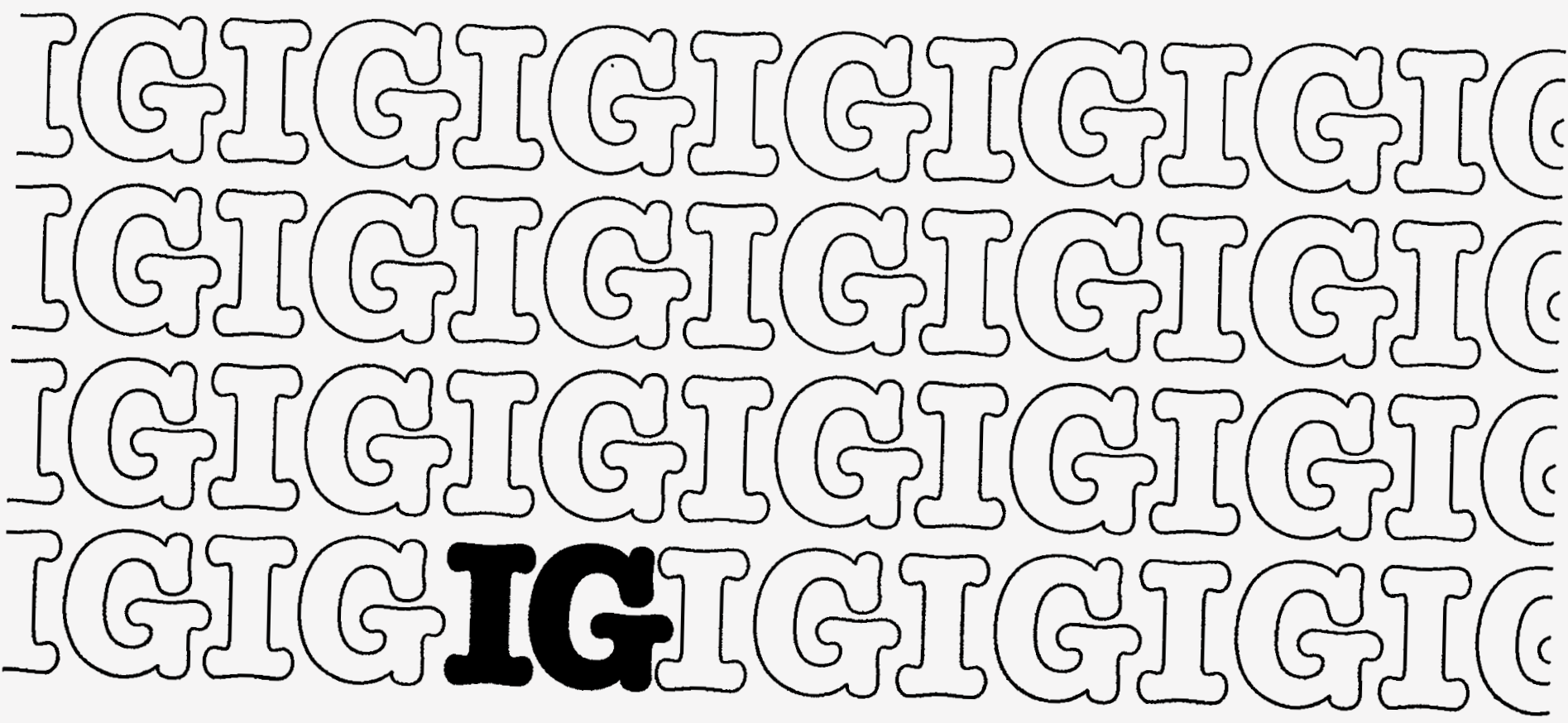


The Office of Inspector General wants to make the distribution of its reports as customer friendly and cost effective as possible. Therefore, this report will be available electronically through the Internet five to seven days after publication at the following alternative addresses:

Department of Energy Headquarters Gopher gopher.hr.doe.gov

Department of Energy Headquarters Anonymous FTP vml . hqadmin.doe.gov

Department of Energy Human Resources and Administration Home Page http://www.hr.doe.gov/refshelf.html

Your comments would be appreciated and can be provided on the Customer Response Form attached to the report.

This report can be obtained from the U.S. Department of Energy office of Scientific and Technical Information P.O. Box 62

Oak Ridge, Tennessee 37831 


\section{DISCLAMMER}

Portions of this document may be illegible in electronic image products. Images are produced from the best available original document. 
U.S. DEPARTMENT OF ENERGY

OFFICE OF INSPECTOR GENERAL

SELECTED CONCERNS REGARDING PROPERTY ACCOUNTABILITY

AT THE CONTINUOUS ELECTRON BEAM ACCELERATOR FACILITY

\section{MASTER}

DISTRIBUTION OF THIS DOCUMENT IS UNLIMITED

Report No. INS-0-96-02

Date Issued: November 24, 1995

Office of Inspections

Washington, D.C. 20585 


\section{SELECTED CONCERNS REGARDING PROPERTY ACCOUNTABILITY AT THE CONTINUOUS ELECTRON BEAM ACCELERATOR FACILITY}

\section{TABLE OF CONTENTS}

Page

I. INTRODUCTION AND PURPOSE $\ldots \ldots \ldots \ldots \ldots \ldots \ldots \ldots \ldots$

II. $\quad$ SCOPE AND METHODOLOGY $\ldots \ldots \ldots \ldots \ldots \ldots \ldots \ldots \ldots$

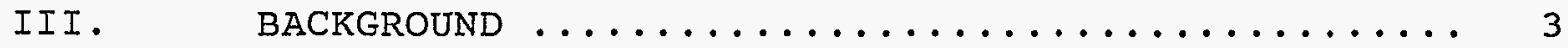

IV. $\quad$ RESULTS OF INSPECTION $\ldots \ldots \ldots \ldots \ldots \ldots \ldots$

Property Custodian Responsibilities ....... 5

Employee Property Out-Processing System .... 7

Identification of Idle Property ......... 8

Physical Inventories and Retirement of Property ................... 9

Property Loan Program ............... 11

Approval of Property Management

Procedures ....................... 12

V. CONCLUSIONS AND RECOMMENDATIONS ........... 14

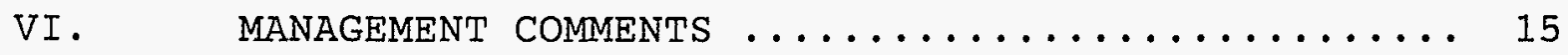




\title{
U.S. DEPARTMENT OF ENERGY \\ OFFICE OF INSPECTOR GENERAL \\ OFFICE OF INSPECTIONS \\ WASHINGTON, DC 20585
}

\begin{abstract}
SELECTED CONCERNS REGARDING PROPERTY ACCOUNTABILITY AT THE CONTINUOUS ELECTRON BEAM ACCELERATOR FACILITY
\end{abstract}

\section{INTRODUCTION AND PURPOSE}

The Continuous Electron Beam Accelerator Facility (CEBAF) is a federally funded research and development center at Newport News, Virginia. At the time of our review, Southeastern Universities Research Association (SURA) was operating CEBAF for the Department of Energy (DOE) under a management and operating (M\&O) contract administered by DOE's Oak Ridge Operations Office. SURA is currently operating CEBAF under a performance based management contract.

The purpose of our inspection was to evaluate selected management issues regarding property accountability at CEBAF that we identified as a result of a complaint received by the Office of Inspector General. The complainant alleged a lack of accountability for Government equipment at CEBAF and the lack of an equipment inventory. Specifically, the complainant alleged, among other things, that after a named supervisor departed, CEBAF personnel had no idea what equipment had been assigned to the supervisor and could not account for any missing materials.

The objectives of our inspection were to:

- Determine whether DOE ensures compliance by SURA/CEBAF with the provisions of the Department's Property Management Regulations (DOE-PMR), which requires SURA/CEBAF to control and account for Government owned property.

- Determine whether DOE's M\&O contract with SURA/CEBAF for operation of CEBAF requires SURA/CEBAF to implement a personal property management system to control and account for Government personal property.

- Determine if SURA/CEBAF is required to implement a Government property management system at CEBAF and, if so; determine whether the system was approved by DOE. 
- Determine if SURA/CEBAF accounted for items assigned to a named individual at the CEBAF site before and after he terminated employment.

\section{SCOPE AND METHODOLOGY}

Our inspection included interviews of DOE officials in the Headquarters Office of Contractor Management and Administration, the DOE Oak Ridge Operations office (OR), and the DOE CEBAF site Office, as well as interviews of SURA/CEBAF officials and officials of Atlas Technology Services, Inc., a subcontractor to SURA/CEBAF at CEBAF. We conducted on-site reviews at CEBAF in February, May, and October of 1994. We reviewed selected Federal and DOE property management regulations applicable to the management of the CEBAF contract and reviewed SURA/CEBAF's property management records, databases, and procedures. To test compliance with Federal and DOE property management requirements, we conducted a limited judgemental sampling of SURA/CEBAF property custodian records, physical inventory procedures, and out-processing records.

This inspection was conducted in accordance with the Quality Standards for Inspections issued by the President's Council on Integrity and Efficiency.

\section{BACKGROUND}

The DOE CEBAF Site Office was established by OR to provide oversight of the M\&O contractor's day-to-day technical and administrative performance. The CEBAF Site office Manager coordinates activities between CEBAF, $O R$, and DOE Headquarters officials. As the CEBAF M\&O contractor, SURA/CEBAF provides services such as research and development, design, construction, management, operations, maintenance, and property managsment in support of CEBAF. A division of Atlas Technology Services, Inc., Applied Research Technology (Atlas Technology), is a subcontractor to SURA/CEBAF. Atlas Technology is responsible for receiving, inventorying, and shipping materiel and equipment, maintaining office supplies, distributing mail, and managing property for CEBAF.

DOE Property Management Regulation (4I CFR Chapter 109)

In accordance with 41 Code of Federal Regulations (CFR) Section 109-1.106-50, "Applicability of Federal and Departmental regulatory issuances," unless otherwise provided in the appropriate part or subpart, contracting officers shall assure 
that the Federal Property Management Regulations (FPMR) and DOE-PMR are applied to contractors. The FPMR and DOE-PMR, as appropriate, shall be used by contracting officers in the administration of contracts, and in the review, approval, or appraisal of such contractor operations.

In accordance with 41 CFR Section 109-1.5201, "Policy," contractors shall establish, maintain, and administer a program for the effective management of Government personal property consistent with the terms of the contract. Contractors shall maintain their personal property management systems in writing and on a current basis.

\section{CEBAF M\&O Contract}

The CEBAF contract "U.S. Department of Energy and Southeastern Universities Research Associates, Inc.," M\&O contract number DE-AC05-84ER40150, Section 44 states:

Property Management. The contractor shall maintain and administer a property management system capable of accounting for and controliing, utilizing, maintaining, repairing, protecting and preserving Government property in its possession under the contract subject to the approval of the contracting officer. The Contractor's property management system shall be maintained and administered in accordance with sound business practice and the Department of Energy's Property Management Regulations and such directives or instructions which the Contracting officer may, from time to time, prescribe by written notice to the Contractor.

\section{RESULTS OF INSPECTION}

As result of our inspection, we identified portions of SURA/CEBAF's personal property management system that did not meet the requirements of DOE property management regulations. For example, we found that SURA/CEBAF property custodians were not adequately performing their responsibilities as custodians and had not received formal training. We also found that the personnel out-processing system implemented by SURA/CEBAF did not ensure that departing employees' property accounts were properly cleared. We found that SURA/CEBAF had not met the requirements for conducting walk-through inspections to identify idle and unneeded personal property and the DOE Contracting Officer had not performed the required review of SURA/CEBAF's walk-through inspection procedures to evaluate their effectiveness. We also found that SURA/CEBAF had not met all the requirements for periodic physical inventories and 
processing of inventory results. We found that SURA/CEBAF had not met all the requirements for management of their property loan program. Finally, we observed that, at the time of our inspection, changes implemented by SURA/CEBAF to their previously approved property management policies and procedures did not have the required approval of the DOE Contracting Officer. However, subsequent to our review, SURA/CEBAF's personal property management system was approved by the oR Property Manager.

\section{Property Custodian Responsibilities}

We found that SURA/CEBAF property custodians were not adequately performing their responsibilities as custodians and had not received formal training.

In accordance with 41 CFR Section 109-1.5002, "Property management program objectives," the "objectives of the DOE property management program are to provide (a) A system for effectively managing Government personal property in the custody or possession of DOE organizations and DOE contractors . . . ."

Also, 41 CFR Section 109-1.5005.5 "Heads of field offices" states that the heads of field offices shall establish and administer a personal property management program within the organization which will:

(b) (10): "Assure that DOE employees and contractors are aware that every user of Government personal property is responsible for its physical protection and for reporting the loss, theft, destruction or damage of property."

In contrast to 41 CFR Section 109-1.5002, we observed that property custodians allowed movement of Government property between locations without notifying property management personnel as required by the CEBAF Personal Property Management Manual. In addition, property was moved between property custodians without preparation of the required DOE Property Movement Forms. Only 2 of the 18 property custodians that we interviewed were aware of the requirement to complete a Property Movement Form when Government property is relocated.

We also reviewed the property accounts held by the 18 property custodians that we interviewed. The following list contains examples of discrepancies noted in four of these property accounts. 
Custodian Organization

1

2

3

4
Physics Division

Physics Division

Physics Division

Accelerator

Division
Discrepancies

a. A printer was not in the assigned location.

b. A printer was not Iisted on the property account.

a. Six "modular channels" were not in the assigned location.

b. Sixteen "modular channels" were not listed on the property account.

a. Three items were assigned to the property account, but the custodian had no knowledge of them.

b. Ten items were moved from their assigned locations, but the locations had not been changed on the property account.

a. Five accountable items were not on the property account.

b. Two items were assigned to the property account, but the custodian had no knowledge of them.

c. A printer was not in the assigned location.

In our view, these discrepancies demonstrate the lack of knowledge by property custodians of their responsibilities, which we believe was partially due to the lack of formal training.

A Contractor Personal Property System Review (CPPSR) of the SURA/CEBAF personal property system conducted during the period December 6-10, 1993, by the DOE Headquarters Office of Contractor Management and Administration had also identified a concern regarding the lack of training by SURA/CEBAF and Atlas Technology property personnel. Although their report, dated December 1993, did not specifically identify a lack of training regarding property custodians, the report contained an 
observation that a formal personal property professional development program did not exist at SURA/CEBAF.

We interviewed 18 SURA/CEBAF property custodians regarding their knowledge of their custodial responsibilities. The custodians that we interviewed lacked general awareness of the full extent of their duties. In addition, none of the 18 property custodians had received training regarding their responsibilities as property custodians. We believe this lack of knowledge of custodial responsibilities contributed to ineffective property management and accountability.

\section{Employee Property Out-Processing System}

We found that SURA/CEBAF had not met the requirements of the DOE-PMR regarding a formal personnel out-processing system to ensure that departing employees' property accounts were properly cleared.

In accordance with 41 CFR Section 109-1.5106-4, written procedures shall be established for control of sensitive items, to include a requirement for employee transfer or termination checkout procedures and subsequent examination and adjustment of records.

The inspection disclosed that the process followed by departing SURA/CEBAF employees to turn in assigned property did not ensure that property was turned in prior to their departure. For example, employees terminating employment with CEBAF were to clear assigned property from the property custodian's account through the SURA/CEBAF Human Resources and Service Department. The Department Director's secretary, who was the only individual in the Division, identified to us as clearing property assigned to departing employees, would telephonically contact Atlas Technology's property monitor to determine if an employee had property assigned to him/her. If the Atlas Technology property monitor was not available, the terminating employee was allowed to depart CEBAF, even though property may have been assigned to the employee. If the Department Director's secretary was not available, the terminating employee was also allowed to depart CEBAF, even though property may have been assigned to the employee.

We judgementally selected and reviewed the property records for 28 of the 103 individuals that terminated employment from CEBAF in Fiscal Years 1992 and 1993. According to the records, four of the 28 employees departed with personal property still charged to their property accounts. The property still charged to the accounts consisted of a total of eight items, having a 
total value of over $\$ 6790$. In our view, six of the eight items, i.e., a telephone, a "frame" cabinet, a multimeter, a computer monitor, a central processing unit, and a graphic monitor, were "sensitive" items as defined by the SURA/CEBAF personal property manual and, therefore, were subject to additional property controls, e.g., employee transfer or termination checkout procedures.

We asked the Director, Human Resources and Service Department, SURA/CEBAF, why written procedures for clearing property accounts by terminating employees had not been developed. He said that although suggested procedures had been developed by a Department staff member, he did not have sufficient time to establish and implement the procedures.

\section{Identification of Idle Property}

We found that SURA/CEBAF had not met all the requirements of the DOE-PMR for conducting walk-through inspections to identify idle and unneeded personal property. Moreover, we found that the DOE Contracting officer had not performed the required review of SURA/CEBAF's walk-through inspection procedures to evaluate their effectiveness.

41 CFR Section 109-25.109-1 (b) "Identification of idle equipment," states that, as a minimum, a management walk-through inspection shall be scheduled to provide for coverage of all operating and storage areas at least once every two years to identify idle and unneeded personal property. It also states that a report of walk-throughs conducted, including participants, areas covered, findings, recommendations, and results achieved shall be submitted to the head of the laboratory or other facility involved.

Also, 41 CFR Section 109-25.109-1 (d) states that contracting officers shall periodically review walk-through procedures and practices of organizations under their jurisdiction to evaluate their effectiveness. This review should include active walk-through inspections of representative DOE or contractor facilities.

At the time of our review, we found no record that the required personal property walk-through inspections to detect idle property had been conducted. In addition, the DOE Contracting Officer said that he had not conducted a review of SURA/CEBAF's walk-through inspection procedures, nor had he conducted a walk-through inspection. 
The report of the CPPSR conducted by the DOE Headquarters Office of Contractor Management and Administration in December 1993 contained the observation that a walk-through inspection of SURA/CEBAF facilities had not been conducted since 1989. However, we do not believe the 1989 inspection met the requirements in the DOE-PMR for walk-through inspections. The basis for the CPPSR observation that a walk-through inspection was conducted in 1989 was a memorandum dated April 24, 1989, Subject: Unrequired Equipment. We reviewed the memorandum, which documented the results of a review by CEBAF's Ad Hoc Blue Ribbon Equipment Review Committee of unrequired equipment. In our view, the Ad Hoc Committee review did not meet the requirements of the DOE-PMR for a walk-through inspection. Specifically, the review did not identify the participants and the areas covered, nor did the memorandum contain recommendations or identify the results achieved.

We performed spot checks in selected areas at CEBAF to identify possible idle equipment and found equipment that was not being utilized. For example, in one maintenance location we observed a printer on a book case that had collected a large amount of dust. Also, in a location in the Accelerator Division, we observed nine central processing units and some computer accessories and cables in storage cabinets.

\section{Physical Inventories and Retirement of Property}

We found that SURA/CEBAF had not met all the requirements of the DOE-PMR for periodic physical inventories of property and processing of inventory results.

41 CFR Section 109-1.5106-5, "Physical inventories," states that physical inventories of property shall be conducted at all DOE and contractor locations, consistent with approved procedures and generally accepted accounting procedures. It states that detailed procedures for conducting physical inventories shall be developed for each DOE organization and contractor. It also states that the appropriate field organization staff shall review and approve the contractor's procedures.

Also, 41 CFR Section 109-1.5107, "Retirement of property," states that when Government property is worn out, lost, stolen, destroyed, abandoned, or damaged beyond economical repair, it shall be listed on a retirement work order. Also, a full explanation shall be supported by an investigation, if necessary, as to the date and circumstances surrounding loss, theft, destruction, abandonment, or damage. In addition, the retirement work order shall be reviewed by the property management staff, signed by the responsible official initiating 
the report, and reviewed and approved by an official at least one supervisory echelon above the official initiating the report.

We determined that SURA/CEBAF policies and procedures for conducting physical inventories did not include certain requirements of the DOE-PMR. Moreover, SURA/CEBAF officials had not conducted thorough searches for missing property. For example, we identified the following conditions during our review.

- Neither the SURA/CEBAF desk-top procedures nor the CEBAF Personal Property Management Manual, in our view, contained adequate detailed procedures to address Federal and DOE inventory requirements. The DOE-PMR ( 41 CFR Section 109-1.5106-5 (c)) requires detailed procedures for taking physical inventories, which shall be developed for each DOE organization and contractor. However, we observed that the SURA/CEBAF inventory procedures addressed only the types of property to be inventoried and inventory timeframes, but did not contain specific procedures for conducting the inventory. For example, the method used to reconcile records for missing property was not addressed in the procedures.

- Although the DOE-PMR (41 CFR Section 109-1.5106-5) required approval of detailed inventory procedures for SURA/CEBAF by OR, the OR Property Management representative had not approved the SURA/CEBAF inventory procedures.

- Inadequate investigations were being performed on items considered missing as a result of annual inventories. Although a listing of items considered missing was forwarded to division directors throughout the CEBAF plant site, if the items were not located, the items were deleted from the property record without further investigation.

- We found no documentation to support the basis for SURA/CEBAF listing items as missing and "written off" on retirement work orders for the Fiscal Year 1992 and 1993 inventories. For example, 17 items were "written off" on a retirement work order for Fiscal Year 1992 and 12 items were "written off" on a retirement work order for Fiscal Year 1993. We were unable to locate, nor could SURA/CEBAF officials provide, documentation to show that research had been performed to locate the missing items.

- Regarding the concern by the complainant about personal property held by a supervisor who had departed, we learned that four items, i.e., a digitizer reader, a computer keyboard, a 
computer monitor, and a personal computer, with a total value of $\$ 4700$, had been charged to the supervisor on his property account. After the supervisor had departed, the property could not be located. We learned from the SURA/CEBAF Property Specialist that the former supervisor had not been contacted regarding the missing property. However, following our inquiries about the missing property, the former supervisor was contacted. We were told by the SURA/CEBAF Property specialist that the former supervisor stated that he thought the missing property had been turned in prior to his departing CEBAF.

According to the SURA/CEBAF Property Officer, missing items identified during the year or as the result of a physical inventory are advertised and, if not found, are written off during the next year's inventory. The four items held by the departed supervisor were written off in the FY 1993 inventory; the inventory for the same year as the items were identified as missing. We learned that one of the four items, a digitizer reader, was subsequently located in the departed supervisor's office during FY 1994.

\section{Property Loan Program}

We found that SURA/CEBAF had not met the DOE-PMR requirements for management of their property loan program.

In accordance with 41 CFR Section 109-1.5104 (a):

"Property which would otherwise be out of service for temporary periods (and not excess) may be loaned to other DOE offices and contractors, other Federal agencies, and to others for official purposes. Such loans shall be covered by written agreement or memorandum receipts which shall include all terms of the loan. . . that may be required to ensure proper control and to protect DOE's interest. The loan period should not exceed one year, but may be renewed."

Our review of a judgemental sample of 16 of the total of $83 \mathrm{DOE}$ Loan Agreement Forms for items on loan in February 1994 revealed that for 75 percent (12 out of 16) of the DOE Loan Agreement Forms selected for review, the loan period had exceeded one year and had not been renewed. The following are examples of loans to four employees that, as of February 1994, exceeded one year without the required renewal. 
Employee

$$
\begin{aligned}
& 1 \\
& 2 \\
& 3 \\
& 4
\end{aligned}
$$

Date Loan Form

Signed

Jan. 1993

Sep. 1992

Dec. 1992

Jan. 1993
Date Renewal

Required

Dec. 1993

Sep. 1993

Dec. 1993

Jan. 1994

Approval of Property Management Procedures

During our inspection, we observed that changes implemented by SURA/CEBAF to their previously approved property management policies and procedures had not been approved by the DOE Property Administrator and the DOE Contracting Officer, as required by the DOE-PMR.

In accordance with 41 CFR Section 109-1.5203 (d), "Review and approval of contractor's property management system, " any changes to the approved property management system made after the original review and approval should be reviewed by the property administrator at the earliest possible. Such changes should then be approved/disapproved by the property administrator as appropriate.

Although the SURA/CEBAF personal property management system was approved in 1991, SURA/CEBAF implemented changes in 1993 to the approved system without obtaining the required approval. BY letter dated september 3, 1991, the DOE CEBAF Site Office Manager notified the Director, SURA/CEBAF, that a report by the OR Property Management and Procurement Policy Branch, which concerned its appraisal of SURA/CEBAF's performance in personal property management, approved the SURA/CEBAF personal property management system. In 1993, SURA/CEBAF developed and implemented major changes to its approved property management system. SURA/CEBAF documented the revised system requirements in a draft property manual, CEBAF Personal Property Management Manual, dated September 1993, which was forwarded to the DOE CEBAF Site Office Property Administrator. The Property Administrator subsequently forwarded the draft property manual to the OR Procurement and Contracts Division for approval. In October 1993, the OR Organizational Property Management Officer returned the draft property manual to the DOE CEBAF Site Office with informal comments and recommended changes. Recommended changes, among others, are as follows:

- The draft manual stated as an objective to "Protect property from loss or damage." The OR Property Officer 
recommended the objective be revised to "Protect property from theft, damage or unauthorized use."

- The draft manual defines sensitive items as "Items of property which have a value of $\$ 150$ or greater and are susceptible to being appropriated for personal use . . . ." The OR Property Officer recommended the definition be changed. He stated that the $\$ 150$ value should not be an across the board threshold; the dollar values may vary for different items.

- The OR Property Officer stated that the requirement in the draft manual to use blue decals for property tagging could cause confusion. He stated that the requirement "could be confusing to receiving and property staff."

- The OR Property Officer stated that the requirement in the draft manual to use the Property Movement Form ". . . is too loose. You will be criticized by HQ. Property passes should be used on computers and cellular phones."

- The OR Property Officer stated that the draft manual did not address the requirement for disposal of non-reportable property.

At the time of our site visit in October 1994, SURA/CEBAF had not received approval of their draft property manual. Also, the DOE CEBAF Site Office Property Administrator stated that he had not reviewed the contractor's property management system, as required by 41 CFR 109-1.5203. Therefore, in our view, he was not in a position to know whether the SURA/CEBAF's property management system could adequately protect, maintain, and utilize Government personal property in its custody in accordance with the $\mathrm{M} \& \mathrm{O}$ contract and previously approved policies and procedures.

In November 1994, following our site visit, the DOE CEBAF Site Office Manager and the DOE Contracting Officer directed SURA/CEBAF to implement changes recommended by OR to their property management system and to accelerate actions to obtain approval of their property management system. We subsequently learned that SURA/CEBAF's Personal Property Management System was approved by the OR Property Manager on December 22, 1994. 


\section{CONCLUSIONS AND RECOMMENDATIONS}

We found portions of SURA/CEBAF's personal property management system that did not meet the requirements of DOE property management regulations. Therefore, we concluded that the SURA/CEBAF personal property management system was not maintained and administered in accordance with the Department's property management regulations, as required by the SURA M\&O contract with the Department for operation of CEBAF. Consequently, in our view, accountability for certain Government equipment was lacking. We believe this condition existed, in part, because the DOE CEBAF Site Office Property Administrator did not provide adequate oversight of the property management requirements of the SURA/CEBAF M\&O contract. We also concluded that the allegation by the complainant concerning missing property that had been assigned to a supervisor that departed was substantiated. We found that SURA/CEBAF could not account for property assigned to the supervisor that was missing after the supervisor departed.

In view of the above, we recommend that the DOE CEBAF site Office Manager:

1. Assure that DOE CEBAF Site Office officials having contract administration responsibilities regarding SURA/CEBAF's personal property management system are performing their responsibilities in accordance with applicable Federal property regulations.

2. Assure that the SURA/CEBAF personal property management system is maintained and administered in accordance with the Department's property management regulations.

3. Assure that SURA/CEBAF provides formal training for property custodians regarding their duties and responsibilities.

4. Assure that SURA/CEBAF develops and implements formal written procedures for out-processing personnel so that departing employees' property accounts are properly cleared.

5. Assure that SURA/CEBAF develops and implements procedures for:

a. conducting required walk-through inspections to identify idle and unneeded personal property, and 
b. processing idle and unneeded property in accordance with Departmental requirements.

6. Assure that SURA/CEBAF develops and implements formal written procedures for:

a. conducting required periodic physical inventories, and

b. processing inventory results in accordance with Departmental requirements.

7. Assure that SURA/CEBAF develops and implements formal written procedures for management of their property loan program in accordance with Departmental requirements.

\section{MANAGEMENT COMMENTS}

In comments dated September 13, 1995, the Acting Chief Financial Officer, Oak Ridge Operations Office (OR), concurred with recommendation numbers $1,2,4,5,6$ and 7 , and concurred in principle with recommendation number 3. The Acting Chief Financial Officer stated that the DOE CEBAF Site Office is administering its obligations under the contract. He stated that over the last two years, the Site office has worked closely with the Headquarters Office of Contractor Management and Administration, the OR Property Management and Procurement Policy Branch, and the Office of Inspector General to see that a personal property management program is developed and managed at CEBAF consistent with property management regulations. He stated that all recommendations listed above were considered closed.

We agree that recommendation numbers $1,2,4,5,6$ and 7 can be closed. However, recommendation number 3 should remain open. Regarding recommendation number 3 , the Acting Chief Financial Officer stated that $O R$ concurs in the spirit of this recommendation. He indicated there are no statutory, régulatory, or contractual requirements to provide formal training for property custodians. However, 41 CFR 109-1.5005-5 does require custodians be made aware of their personal property management responsibilities. SURA/CEBAF has committed to prepare a one-page guide for every property custodian to highlight their key responsibilities and directions on how to attain one-on-one training. 
In comments dated September 29, 1995, the Chief Financial Officer agreed that recommendation number 3 should be held open pending completion of the guide for property custodians by the contractor. This guide is targeted to be completed and reviewed by the CEBAF Site Office by November 30, 1995. 
IG Report No. INS-0-96-02

\section{CUSTOMER RESPONSE FORM}

The Office of Inspector General has a continuing interest in improving the usefulness of its products. We wish to make our reports as responsive as possible to our customers' requirements, and therefore ask that you consider sharing your thoughts with us. On the back of this form, you may suggest improvements to enhance the effectiveness of future reports. Please include answers to the following questions if they are applicable to you:

1. What additional background information about the selection, scheduling, scope, or procedures of the audit or inspection would have been helpful to the reader in understanding this report?

2. What additional information related to findings and recommendations could have been included in this report to assist management in implementing corrective actions?

3. What format, stylistic, or organizational changes might have made this report's overall message more clear to the reader?

4. What additional actions could the Office of Inspector General have taken on the issues discussed in this report which would have been helpful?

Please include your name and telephone number so that we may contact you should we have any questions about your comments.

$\begin{array}{ll}\text { Name_Late } & \text { Datization } \\ \text { Telephone___ Organiza }\end{array}$

When you have completed this form, you may telefax it to the office of Inspector General at (202) 586-0948, or you may mail it to:

Office of Inspector General (IG-1)

Department of Energy

Washington, D.C. 20585

ATTN: Customer Relations

If you wish to discuss this report or your comments with a staff member of the Office of Inspector General, please contact Wilma Slaughter at (202) 586-1924. 